\title{
Synthesis of Single-Walled Carbon Nanotubes: Effects of Active Metals, Catalyst Supports, and Metal Loading Percentage
}

\author{
Wei-Wen Liu, ${ }^{1,2}$ Azizan Aziz, ${ }^{2}$ Siang-Piao Chai, ${ }^{3}$ \\ Abdul Rahman Mohamed, ${ }^{4}$ and U. Hashim ${ }^{1}$ \\ ${ }^{1}$ Institute of Nano Electronic Engineering (INEE), Universiti Malaysia Perlis (UniMAP), 01000 Kangar, Perlis, Malaysia \\ ${ }^{2}$ School of Materials and Mineral Resources Engineering, Engineering Campus, Universiti Sains Malaysia, \\ Seberang Perai Selatan, 14300 Nibong Tebal, Pulau Pinang, Malaysia \\ ${ }^{3}$ School of Engineering, Monash University, Jalan Lagoon Selatan, 46150 Bandar Sunway, Selangor, Malaysia \\ ${ }^{4}$ School of Chemical Engineering, Engineering Campus, Universiti Sains Malaysia, Seberang Perai Selatan, 14300 Nibong Tebal, \\ Pulau Pinang, Malaysia
}

Correspondence should be addressed to Abdul Rahman Mohamed; chrahman@eng.usm.my

Received 12 April 2013; Revised 5 June 2013; Accepted 13 June 2013

Academic Editor: Shiren Wang

Copyright (C) 2013 Wei-Wen Liu et al. This is an open access article distributed under the Creative Commons Attribution License, which permits unrestricted use, distribution, and reproduction in any medium, provided the original work is properly cited.

The effects of active metals, catalyst supports, and metal loading percentage on the formation of single-walled carbon nanotubes (SWNTs) were studied. In particular, iron, cobalt, and nickel were investigated for SWNTs synthesis. Iron was found to grow better-quality SWNTs compared to cobalt and nickel. To study the effect of catalyst supports, magnesium oxide, silicon oxide, and aluminium oxide were chosen for iron. Among the studied supports, $\mathrm{MgO}$ was identified to be a suitable support for iron as it produced SWNTs with better graphitisation determined by Raman analysis. Increasing the iron loading decreased the quality of SWNTs due to extensive agglomeration of the iron particles. Thus, lower metal loading percentage is preferred to grow better-quality SWNTs with uniform diameters.

\section{Introduction}

Besides laser evaporation and electric arc discharge methods, the catalytic chemical vapor deposition (CVD) is a very efficient method to synthesize single-walled carbon nanotubes (SWNTs) on a large scale but a low cost [1-3]. It is well known that the catalyst is indispensable for the growth of SWNTs in CVD process. A variety of metal catalysts such as $\mathrm{Au}, \mathrm{Ag}$, $\mathrm{Pt}, \mathrm{Pd}, \mathrm{Mn}, \mathrm{Mo}, \mathrm{Cu}, \mathrm{Rh}, \mathrm{Zn}, \mathrm{Cr}, \mathrm{Ru}, \mathrm{Mg}$, and $\mathrm{Al}$ have been used for the production of SWNTs [4-11]. However, Fe, Co, $\mathrm{Ni}$, and their alloys are the most of the widely used transition metal catalysts for SWNT production [12-14]. So far, various substances have been tested as supports of catalytically active metals, for instance, zeolites [15, 16], $\mathrm{SiO}_{2}$ [17], $\mathrm{Al}_{2} \mathrm{O}_{3}$ [18], $\mathrm{CaCO}_{3}$ [19], and $\mathrm{MgO}$ [20]. The interactions between the support and active metal are greatly important in the synthesis of SWNTs because it can affect the quality of SWNTs.
In addition, the dependency of structure upon property causes the structure control and large-scale production of SWNTs to become one of the crucial topics in carbon related scientific communities [21-25]. Clear understanding of underlying growth mechanisms is therefore of significant importance in promoting the development and innovations of SWNTs.

Thus, there is a need to investigate the effects of active metals, catalyst supports, and metal loading percentage on the production of SWNTs. Our previous study shows that $\mathrm{Fe}_{3} \mathrm{O}_{4} / \mathrm{MgO}$ was an effective catalyst for growing SWNTs [26-29]. We had also reported that the quality of SWNTs was affected by the types of carbon precursors used [27]. In this work, the effects of active metals such as $\mathrm{Fe}, \mathrm{Ni}$, and $\mathrm{Co}$ were chosen because they are believed to yield high quality of SWNTs, but we are unsure which active metals can synthesise the highest quality of SWNT when supported by $\mathrm{MgO}$ under 
our reaction conditions. It is because a minor change on the reaction parameters can influence the active metals' performances. In the second study, the best performance active metal was supported by $\mathrm{MgO}, \mathrm{SiO}_{2}$, and $\mathrm{Al}_{2} \mathrm{O}_{3}$ to investigate the interaction between supports and active metal which can affect the yield of SWNTs. At last study, different metal loading percentages were set to examine the effect on the quality of SWNTs.

\section{Experimental Procedures}

2.1. Preparation of the Catalyst. The preparation method for $\mathrm{Fe}_{3} \mathrm{O}_{4}$ nanoparticles has been previously reported [29]. The molar ratios of $\mathrm{Fe}_{3} \mathrm{O}_{4}$ to $\mathrm{MgO}, \mathrm{NiO}$ to $\mathrm{MgO}$, and $\mathrm{CoO}$ to $\mathrm{MgO}$ were set at $1: 9 . \mathrm{Fe}_{3} \mathrm{O}_{4} / \mathrm{MgO}, \mathrm{NiO} / \mathrm{MgO}$, and $\mathrm{CoO} / \mathrm{MgO}$ catalysts were prepared by dispersing $\mathrm{MgO}$ (99.99\% trace metal basis: Aldrich) in distilled water and subsequently adding the required amount of $\mathrm{Fe}_{3} \mathrm{O}_{4}$ nanoparticles, $\mathrm{Ni}$ $\left(\mathrm{NO}_{3}\right)_{2} \cdot 6 \mathrm{H}_{2} \mathrm{O}(99.999 \%$ trace metal basis: Aldrich) and Co $\left(\mathrm{NO}_{3}\right)_{2} \cdot 6 \mathrm{H}_{2} \mathrm{O}$ (99.999\% trace metal basis: Aldrich), respectively, into the $\mathrm{MgO}$ solution to get three different types of mixture solutions. For the preparation of $\mathrm{Fe}_{3} \mathrm{O}_{4} / \mathrm{Al}_{2} \mathrm{O}_{3}$ and $\mathrm{Fe}_{3} \mathrm{O}_{4} / \mathrm{SiO}_{2}$ catalysts, the molar ratios of $\mathrm{Fe}_{3} \mathrm{O}_{4}$ to $\mathrm{Al}_{2} \mathrm{O}_{3}$ and $\mathrm{Fe}_{3} \mathrm{O}_{4}$ to $\mathrm{SiO}_{2}$ were set at 1:9. The required amount of $\mathrm{Fe}_{3} \mathrm{O}_{4}$ nanoparticles was dispersed in distilled water and followed by adding $\mathrm{Al}_{2} \mathrm{O}_{3}$ (analytical reagents: Ajax) and $\mathrm{SiO}_{2}$ nanopowder (analytical reagents: $\mathrm{RdH}$ ), respectively, to form two different types of mixture solutions. To prepare different molar ratios of $\mathrm{Fe}_{3} \mathrm{O}_{4} / \mathrm{MgO}$ catalysts at $1.75: 8.25$, $2.5: 7.5$, and $3.25: 6.75$, the same procedure as above was used. All mixture solutions were then sonicated for $10 \mathrm{~min}$, and water was removed by rotary evaporation. Finally, the dried catalyst was ground with a pestle and mortar to break the agglomerates into a very fine powder.

2.2. Synthesis of SWNTs. The synthesis of SWNTs was carried out at atmospheric pressure in a quartz tube placed vertically in a stainless-steel housing [26-29]. For the synthesis of SWNTs, $0.2 \mathrm{~g}$ of the catalyst was distributed in the centre of the reactor for each run. The reactor was heated in a tubular furnace to $900^{\circ} \mathrm{C}$ in a nitrogen atmosphere $(99.999 \%$ purity) at a flow rate of $40 \mathrm{~mL} / \mathrm{min}$. Subsequently, high-purity methane $(99.999 \%$ purity) was mixed with nitrogen at a ratio of $1: 1(\mathrm{v} / \mathrm{v})$ before introducing the mixed gas into the reactor at a total flow rate of $80 \mathrm{~mL} / \mathrm{min}$. The reaction was kept under these conditions for $30 \mathrm{~min}$. After the reaction, the furnace was cooled to room temperature in a nitrogen flow.

2.3. Characterization of SWNTs. The carbon samples, in black powder form, were collected from the quartz reactor for detail characterisation. The morphology of the SWNTs was investigated using transmission electron microscopy (TEM; Philips CM12) and scanning electron microscopy (SEM; Supra $35 \mathrm{VP}$ ). Raman spectrum measurements were conducted on the carbon samples using a Raman spectroscopy (inVia Renishaw) at a wavelength of $633 \mathrm{~nm}$.

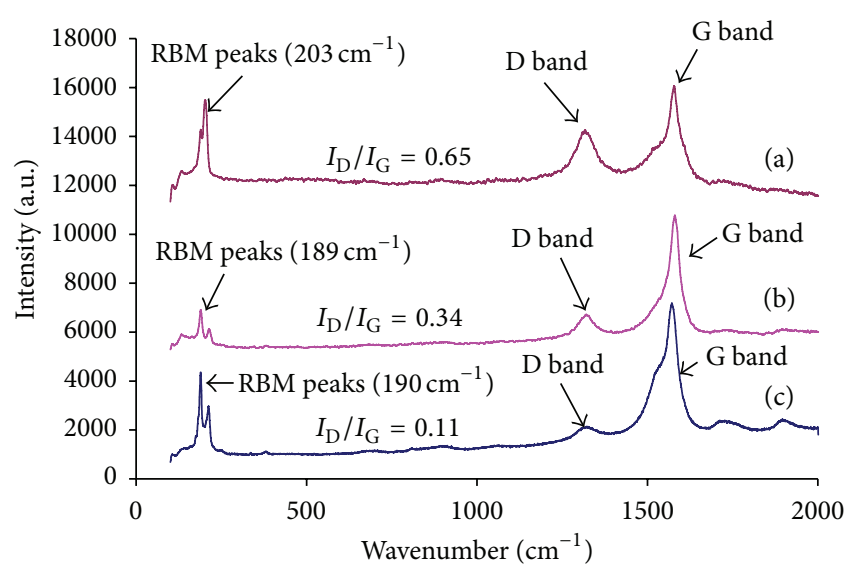

Figure 1: Raman spectra of the (a) $\mathrm{NiO} / \mathrm{MgO}$, (b) $\mathrm{CoO} / \mathrm{MgO}$, and (c) $\mathrm{Fe}_{3} \mathrm{O}_{4} / \mathrm{MgO}$ catalysts after reaction.

\section{Results and Discussion}

3.1. Effect of $\mathrm{Fe}_{3} \mathrm{O}_{4}, \mathrm{NiO}$, and $\mathrm{CoO}$ Supported on $\mathrm{MgO}$. The ability of $\mathrm{Fe}_{3} \mathrm{O}_{4} / \mathrm{MgO}, \mathrm{NiO} / \mathrm{MgO}$, and $\mathrm{CoO} / \mathrm{MgO}$ catalysts to produce SWNTs was investigated. The study was based on the $I_{\mathrm{D}} / I_{\mathrm{G}}$ ratio from Raman spectra of SWNTs produced over these catalysts. The $I_{\mathrm{D}} / I_{\mathrm{G}}$ ratio is commonly used as a measure of the quality of CNTs produced: a smaller $I_{\mathrm{D}} / I_{\mathrm{G}}$ ratio corresponds to a higher quality structure or fewer defects [30]. The $I_{\mathrm{D}} / I_{\mathrm{G}}$ ratios for samples produced by $\mathrm{Fe}_{3} \mathrm{O}_{4} / \mathrm{MgO}, \mathrm{NiO} / \mathrm{MgO}$, and $\mathrm{CoO} / \mathrm{MgO}$ catalysts were $0.11,0.65$, and 0.34 , respectively, decreasing in the order of $\mathrm{NiO} / \mathrm{MgO}>\mathrm{CoO} / \mathrm{MgO}>\mathrm{Fe}_{3} \mathrm{O}_{4} / \mathrm{MgO}$. A high $I_{\mathrm{D}} / I_{\mathrm{G}}$ ratio of 0.65 was obtained for the $\mathrm{NiO} / \mathrm{MgO}$ catalyst, indicating that a low-quality structure was formed. The $\mathrm{Fe}_{3} \mathrm{O}_{4} / \mathrm{MgO}$ catalyst formed better-quality CNTs where $I_{\mathrm{D}} / I_{\mathrm{G}}$ ratio of 0.11 was obtained. Figure 1 shows the Raman spectra of the three different catalyst systems after reaction. The presence of the radial breathing mode (RBM) and G- and D-bands in the Raman spectra confirms the presence of SWNTs. The frequency of the RBM is inversely proportional to the diameter of the nanotube from which it arises. It has been found empirically that the diameter of the tube $\left(d_{t} / \mathrm{nm}\right)$ can relate to the frequency of RBM by $\omega \mathrm{RBM}=A / d_{t}+B$, where $A=234 \mathrm{~cm}^{-1}, B=10 \mathrm{~cm}^{-1}$, and $d_{t}=$ diameter of SWNTs in nanometer [31].

It is important to note the significant peaks at Raman shifts of 203 and $190 \mathrm{~cm}^{-1}$, which correspond to the nanotube diameters of $1.22,1.30$, and $1.31 \mathrm{~nm}$ produced by the $\mathrm{NiO} / \mathrm{MgO}, \mathrm{CoO} / \mathrm{MgO}$, and $\mathrm{Fe}_{3} \mathrm{O}_{4} / \mathrm{MgO}$ catalysts, respectively. The nanotube samples were also characterised using transmission electron microscopy (TEM) and their results are shown in Figure 2. It can be observed that bundles of SWNTs with nearly uniform diameters were synthesised by $\mathrm{Fe}_{3} \mathrm{O}_{4} / \mathrm{MgO}, \mathrm{NiO} / \mathrm{MgO}$, and $\mathrm{CoO} / \mathrm{MgO}$ catalysts. Bundles that consist of more than 20 SWNTs were obtained from the $\mathrm{Fe}_{3} \mathrm{O}_{4} / \mathrm{MgO}$ catalyst. In addition to the SWNT bundles, MWNTs were also observed under TEM for the $\mathrm{NiO} / \mathrm{MgO}$ catalyst but not for the $\mathrm{Fe}_{3} \mathrm{O}_{4} / \mathrm{MgO}$ and $\mathrm{CoO} / \mathrm{MgO}$ catalysts.

To arrive at the understanding why the $\mathrm{Fe}_{3} \mathrm{O}_{4} / \mathrm{MgO}$ catalyst formed SWNTs with a lower $I_{\mathrm{D}} / I_{\mathrm{G}}$ ratio, we have 


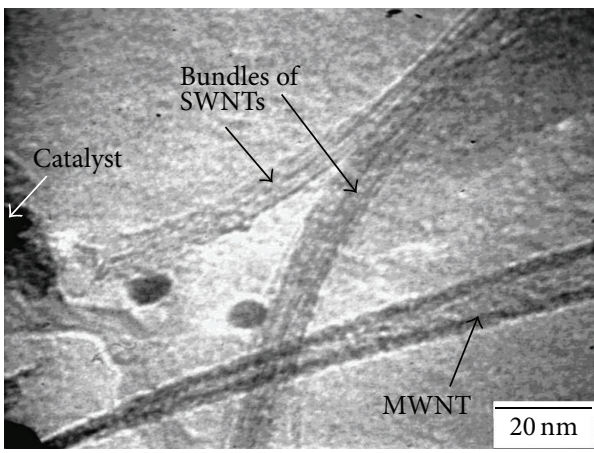

(a)

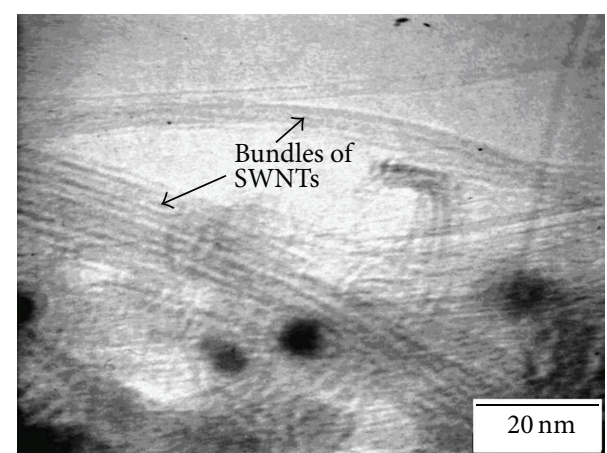

(b)

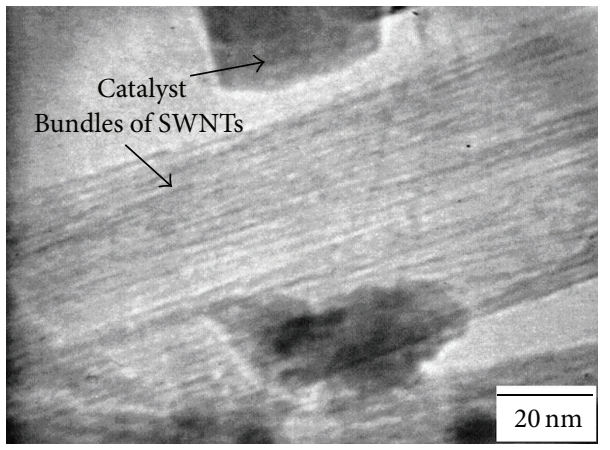

(c)

Figure 2: TEM images showing SWNT bundles synthesised by the (a) $\mathrm{NiO} / \mathrm{MgO}$, (b) $\mathrm{CoO} / \mathrm{MgO}$, and (c) $\mathrm{Fe}_{3} \mathrm{O}_{4} / \mathrm{MgO}$ catalysts.

to understand the carbon solubility for $\mathrm{Fe}, \mathrm{Ni}$, and Co. Moisala et al. [31] reported that the carbon solubilities for $\mathrm{Fe}, \mathrm{Co}$, and $\mathrm{Ni}$ are 20.2, 13.9, and $10.7 \%$, respectively, at a given temperature. Fe has the highest carbon solubility as compared with $\mathrm{Co}$ and $\mathrm{Ni}$. The higher carbon solubility of Fe influences CNT nucleation and growth in several ways: (i) increasing the carbon availability for CNT growth; (ii) creating a higher concentration driving force to accelerate the CNT formation rate; (iii) affecting nucleation of CNT caps; and (iv) determining the type of CNT grown [32]. By thermodynamic analysis, Kuznetsov et al. [33] reported that the morphology of nanotubes is a function of two parameters: the diameter of the catalyst particle and the carbon supersaturation ratio. When the supersaturation value is high, carbon caps can be formed easily from the multiple carbon nuclei on the same particle surface. Due to the van der Waals forces, the SWNTs may be reoriented to form SWNT bundles. Therefore, Fe tends to have a higher carbon supersaturation ratio compared with $\mathrm{Co}$ and Ni because of its higher carbon solubility of $\mathrm{Fe}$, which promotes the nucleation and growth of SWNTs and also explains why broad bundles of SWNTs with a more highly graphitised structure were formed on the $\mathrm{Fe}_{3} \mathrm{O}_{4} / \mathrm{MgO}$ catalyst.

3.2. Effect of $\mathrm{Al}_{2} \mathrm{O}_{3}, \mathrm{SiO}_{2}$, and $\mathrm{MgO}$ Supports. Figure 3 shows the Raman spectra for samples produced by $\mathrm{Fe}_{3} \mathrm{O}_{4}$ supported on $\mathrm{SiO}_{2}, \mathrm{Al}_{2} \mathrm{O}_{3}$, and $\mathrm{MgO}$. The $I_{\mathrm{D}} / I_{\mathrm{G}}$ ratio for samples produced by $\mathrm{Fe}_{3} \mathrm{O}_{4}$ supported on $\mathrm{SiO}_{2}, \mathrm{Al}_{2} \mathrm{O}_{3}$, and $\mathrm{MgO}$ were $0.34,0.29$, and 0.11 , respectively. $\mathrm{RBM}$ in the range

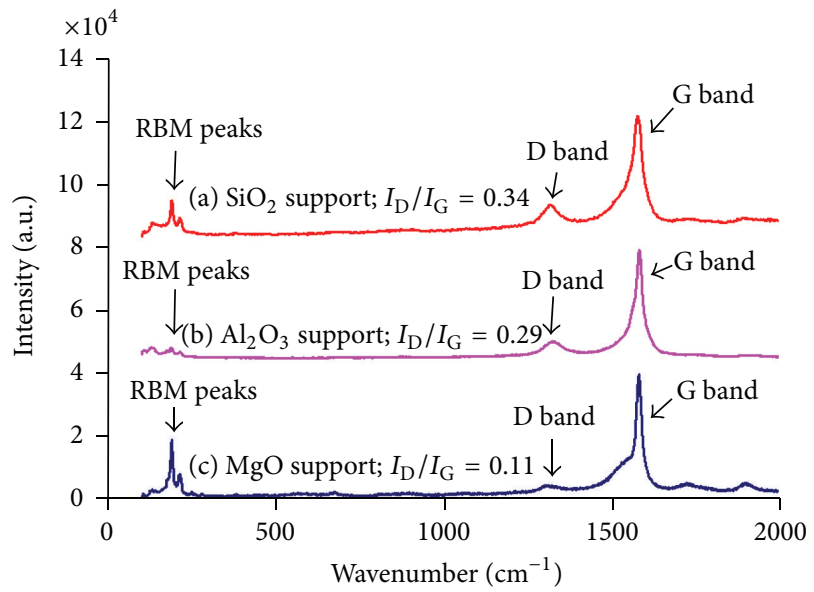

Figure 3: Raman spectra of the (a) $\mathrm{Fe}_{3} \mathrm{O}_{4} / \mathrm{SiO}_{2}$, (b) $\mathrm{Fe}_{3} \mathrm{O}_{4} / \mathrm{Al}_{2} \mathrm{O}_{3}$, and (c) $\mathrm{Fe}_{3} \mathrm{O}_{4} / \mathrm{MgO}$ catalysts after reaction.

of $100-350 \mathrm{~cm}^{-1}$ are attributed to the presence of SWNTs [34]. In Figure 3, RBM peaks were observed for all three catalysts investigated, revealing the formation of SWNTs. The intensity of $\mathrm{RBM}$ peaks decreased in the following order of $\mathrm{Fe}_{3} \mathrm{O}_{4} / \mathrm{MgO}>\mathrm{Fe}_{3} \mathrm{O}_{4} / \mathrm{SiO}_{2}>\mathrm{Fe}_{3} \mathrm{O}_{4} / \mathrm{Al}_{2} \mathrm{O}_{3}$, whereas the $I_{\mathrm{D}} / I_{\mathrm{G}}$ ratio decreased in the order of $\mathrm{Fe}_{3} \mathrm{O}_{4} / \mathrm{SiO}_{2}>$ $\mathrm{Fe}_{3} \mathrm{O}_{4} / \mathrm{Al}_{2} \mathrm{O}_{3}>\mathrm{Fe}_{3} \mathrm{O}_{4} / \mathrm{MgO}$. In other words, compared with $\mathrm{SiO}_{2}$ and $\mathrm{Al}_{2} \mathrm{O}_{3}, \mathrm{MgO}$-supported $\mathrm{Fe}_{3} \mathrm{O}_{4}$ represents the most suitable combination to produce SWNTs, considering that the highest intensity of RBM peaks and the lowest $I_{\mathrm{D}} / I_{\mathrm{G}}$ 


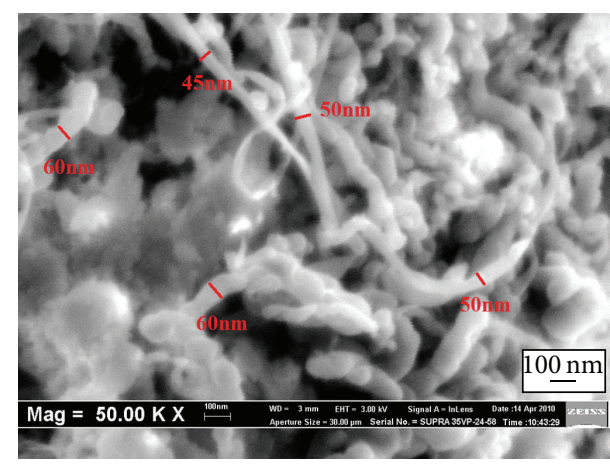

(a)

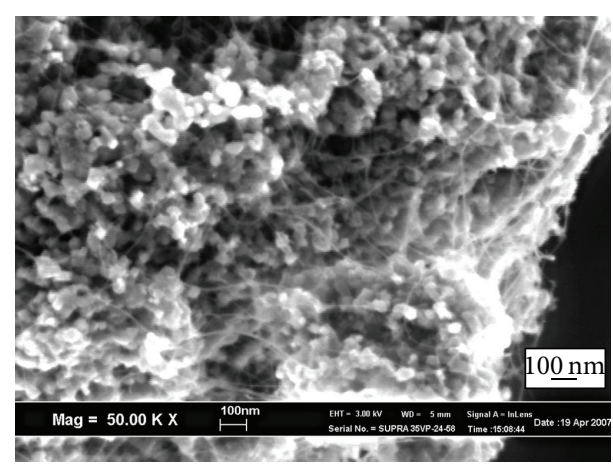

(b)

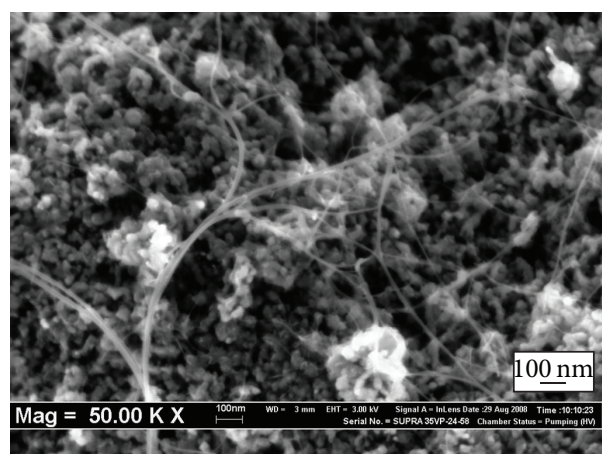

(c)

FIGURE 4: SEM images showing nanotube structure synthesised using the (a) $\mathrm{Fe}_{3} \mathrm{O}_{4} / \mathrm{SiO}_{2}$, (b) $\mathrm{Fe}_{3} \mathrm{O}_{4} / \mathrm{Al}_{2} \mathrm{O}_{3}$, and (c) $\mathrm{Fe}_{3} \mathrm{O}_{4} / \mathrm{MgO}$ catalysts.

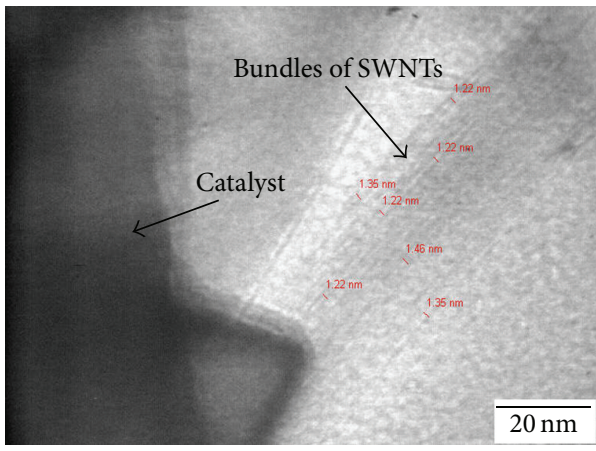

(a)

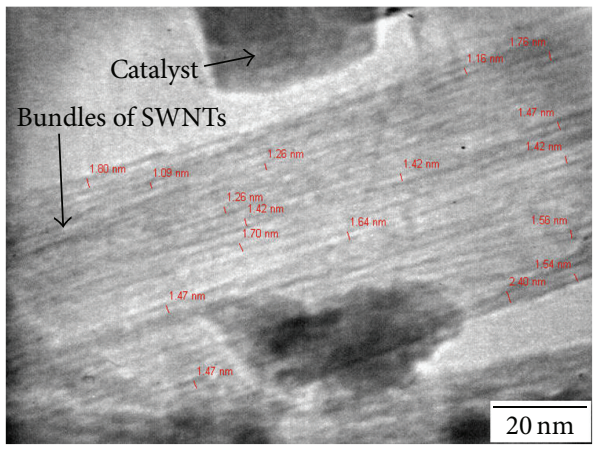

(b)

FIgURE 5: TEM images showing SWNT bundles synthesised using the (a) $\mathrm{Fe}_{3} \mathrm{O}_{4} / \mathrm{Al}_{2} \mathrm{O}_{3}$ and (b) $\mathrm{Fe}_{3} \mathrm{O}_{4} / \mathrm{MgO}$ catalysts.

ratio were observed. This is in good agreement with the finding reported by Ago et al. [35] and Jin et al. [36] that high quality of SWNTs were synthesised by iron supported on $\mathrm{MgO}$ catalyst.

The diameter of SWNTs obtained was in the range of $1.09-2.40 \mathrm{~nm}$. In this work, CNTs with diameters greater than $2.48 \mathrm{~nm}$ were considered large diameter CNTs, whereas CNTs with diameters of $2.48 \mathrm{~nm}$ or less were defined as small-diameter CNTs. Scanning electron microscopy (SEM) images for all samples are shown in Figure 4. CNTs with diameters greater than $2.48 \mathrm{~nm}$ were produced when $\mathrm{SiO}_{2}$ was used as a catalyst support (Figure 4(a)), whereas CNTs with small diameters were formed when $\mathrm{Al}_{2} \mathrm{O}_{3}$ and $\mathrm{MgO}$ were used (Figures 4(b) and 4(c)). The diameters of CNTs synthesised by $\mathrm{Fe}_{3} \mathrm{O}_{4}$ supported on $\mathrm{Al}_{2} \mathrm{O}_{3}$ and $\mathrm{MgO}$ were measured using TEM, and the results are shown in Figure 5. The diameter ranges were $1.22-1.46 \mathrm{~nm}$ and $1.09-2.40 \mathrm{~nm}$ for CNTs produced by $\mathrm{Al}_{2} \mathrm{O}_{3}$ and $\mathrm{MgO}$ when used as catalyst supports, respectively. The diameters were almost uniform, and the CNTs attached to one another in a bundle form (Figure 5). The bundle produced by the $\mathrm{MgO}$-supported catalyst consisted of more SWNTs compared with that produced by $\mathrm{Al}_{2} \mathrm{O}_{3}$ as the catalyst support (Figure 5). The TEM observations show that SWNTs synthesised by MgO used as the support were of high quality, which is consistent with the Raman analysis. 
To understand why $\mathrm{MgO}$ was a superior support, we considered the interaction between the metal oxide nanoparticle and its support. The formation of the highest-quality SWNTs by the $\mathrm{Fe}_{3} \mathrm{O}_{4} / \mathrm{MgO}$ catalyst could be attributed to the strong metal interaction between the $\mathrm{Fe}_{3} \mathrm{O}_{4}$ nanoparticles and $\mathrm{MgO}[37,38]$. This strong interaction restricted the mobility of $\mathrm{Fe}_{3} \mathrm{O}_{4}$ nanoparticles during CVD, thus preventing the extensive agglomeration of $\mathrm{Fe}_{3} \mathrm{O}_{4}$ nanoparticles at high temperatures to form larger-sized clusters, leading to good dispersion of $\mathrm{Fe}_{3} \mathrm{O}_{4}$ [39]. This strong interaction can be explained in terms of Lewis acid/base interactions between metal oxide supports and metal catalyst nanoparticles. A Lewis base is a species that acts as an electron pair donor, whereas a Lewis acid is a species that acts as an electron pair acceptor [39]. In this case, the metal oxide support $(\mathrm{MgO})$ acts as a Lewis base and donates electrons through metal catalyst nanoparticles $\left(\mathrm{Fe}_{3} \mathrm{O}_{4}\right)$ to methane [39]. The metal catalyst nanoparticles play the role of a conduit for transferring negative charge from the metal oxide support to methane. Generally, simultaneous back-donation from methane also takes place that is, methane acts as a Lewis base, whereas $\mathrm{MgO}$ acts as a Lewis acid. The electronic structure of methane is then changed in such a way that decomposition of the methane molecule takes place.

The surface basicity was reported to decrease in the following order: $\mathrm{MgO}>\mathrm{Al}_{2} \mathrm{O}_{3}>\mathrm{SiO}_{2}$ [40]. Thus, $\mathrm{MgO}$ represents the best electron donor compared with $\mathrm{Al}_{2} \mathrm{O}_{3}$ and $\mathrm{SiO}_{2}$. As a result, the interaction between $\mathrm{Fe}_{3} \mathrm{O}_{4}$ and $\mathrm{MgO}$ was stronger than the interactions between $\mathrm{Fe}_{3} \mathrm{O}_{4}$ and $\mathrm{Al}_{2} \mathrm{O}_{3}$ and between $\mathrm{Fe}_{3} \mathrm{O}_{4}$ and $\mathrm{SiO}_{2}$ [40]. With the strong interaction between the $\mathrm{Fe}_{3} \mathrm{O}_{4}$ and $\mathrm{MgO}, \mathrm{Fe}_{3} \mathrm{O}_{4}$ particles are thought to be well dispersed and promote the formation of SWNTs. This explains the reason of intensity of the RBM peaks for the samples produced by $\mathrm{MgO}$ used as a catalyst support was the highest and the $I_{\mathrm{D}} / I_{\mathrm{G}}$ ratio was the lowest compared with the samples formed by $\mathrm{SiO}_{2}$ and $\mathrm{Al}_{2} \mathrm{O}_{3}$. The second highest intensity of RBM peaks was observed for samples formed by $\mathrm{SiO}_{2}$ used as the catalyst support compared with the samples produced by $\mathrm{Al}_{2} \mathrm{O}_{3}$ used as the catalyst support. However, a higher $I_{\mathrm{D}} / I_{\mathrm{G}}$ ratio was observed in the Raman spectra of the sample produced by using an $\mathrm{SiO}_{2}$ catalyst support than that formed when using an $\mathrm{Al}_{2} \mathrm{O}_{3}$ catalyst support. This indicates that more defective structures were formed in the samples due to the fact that $\mathrm{SiO}_{2}$ is a less active support compared with alumina [41, 42]. Because $\mathrm{Al}_{2} \mathrm{O}_{3}$ is an amphoteric material having the characteristics of both an acid and a base, it may take part in the strong interaction. Therefore, $\mathrm{Fe}_{3} \mathrm{O}_{4}$ particles had a better dispersion on the $\mathrm{Al}_{2} \mathrm{O}_{3}$ compared with $\mathrm{SiO}_{2}$ due to this strong interaction and formed a higher degree of CNT graphitisation.

3.3. Effect of $\mathrm{Fe}_{3} \mathrm{O}_{4}$ Loading. In this study, the molar ratios of $\mathrm{Fe}$ to $\mathrm{MgO}$ were varied at $1: 9,1.75: 8.25$, $2.5: 7.5$, and 3.25:6.75, which were denoted as $\left(\mathrm{Fe}_{3} \mathrm{O}_{4}\right)_{1}(\mathrm{MgO})_{9},\left(\mathrm{Fe}_{3} \mathrm{O}_{4}\right)_{1.75}(\mathrm{MgO})_{8.25},\left(\mathrm{Fe}_{3} \mathrm{O}_{4}\right)_{2.5}(\mathrm{MgO})_{7.5}$, and $\left(\mathrm{Fe}_{3} \mathrm{O}_{4}\right)_{3.25}(\mathrm{MgO})_{6.75}$, respectively. The CVD conducted using a molar ratio of $1: 9$ produced the lowest $I_{\mathrm{D}} / I_{\mathrm{G}}$ ratio, that is, 0.11 . The $I_{\mathrm{D}} / I_{\mathrm{G}}$ ratios of samples were found to

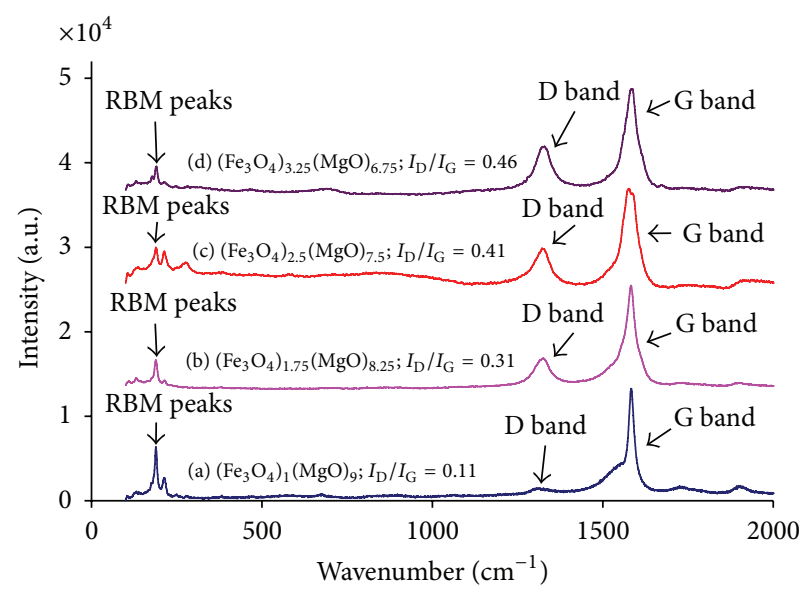

Figure 6: Raman spectra of the (a) $\left(\mathrm{Fe}_{3} \mathrm{O}_{4}\right)_{1}(\mathrm{MgO})_{9}$, (b) $\left(\mathrm{Fe}_{3} \mathrm{O}_{4}\right)_{1.75}(\mathrm{MgO})_{8.25}, \quad$ (c) $\left(\mathrm{Fe}_{3} \mathrm{O}_{4}\right)_{2.5}(\mathrm{MgO})_{7.5}$, and (d) $\left(\mathrm{Fe}_{3} \mathrm{O}_{4}\right)_{3.25}(\mathrm{MgO})_{6.75}$ catalysts after reaction.

increase from 0.11 to 0.46 as the $\mathrm{Fe}_{3} \mathrm{O}_{4}$ loading increased from 1 to 3.25 .

The Raman spectra shown in Figure 6 show the presence of RBM peaks, indicating the presence of SWNTs. The intensity of RBM peaks decreased in the following order for $\mathrm{Fe}_{3} \mathrm{O}_{4}$ loading: $1>1.75>2.5>3.25$. The $I_{\mathrm{D}} / I_{\mathrm{G}}$ ratio was found to decrease in the following order: $3.25>2.5>1.75>1$. In contrast, the highest intensity of RBM peak and the lowest $I_{\mathrm{D}} / I_{\mathrm{G}}$ ratio were observed for SWNTs produced by a catalyst with a molar ratio of $1: 9$.

The SEM images, shown in Figures $7(a)$ and $7(b)$, revealed the presence of narrow-diameter CNTs from $\left(\mathrm{Fe}_{3} \mathrm{O}_{4}\right)_{1}(\mathrm{MgO})_{9}$ and $\left(\mathrm{Fe}_{3} \mathrm{O}_{4}\right)_{1.75}(\mathrm{MgO})_{8.25}$ catalysts. The narrow CNTs grew over the entire catalyst surface with almost uniform diameters. However, large-diameter CNTs were observed in the samples formed by the $\left(\mathrm{Fe}_{3} \mathrm{O}_{4}\right)_{2.5}(\mathrm{MgO})_{7.5}$ and $\left(\mathrm{Fe}_{3} \mathrm{O}_{4}\right)_{3.25}(\mathrm{MgO})_{6.75}$ catalysts. The structures of large CNTs were poor and had inconsistent diameters, which can be seen in Figures 7(c) and 7(d).

To measure the diameters of narrow CNTs, samples produced by the $\left(\mathrm{Fe}_{3} \mathrm{O}_{4}\right)_{1}(\mathrm{MgO})_{9}$ and $\left(\mathrm{Fe}_{3} \mathrm{O}_{4}\right)_{1.75}(\mathrm{MgO})_{8.25}$ catalysts were characterised by TEM. The measured diameter was in the range of 1.16-2.10 nm and 1.10-1.85 nm for SWNTs synthesised by $\left(\mathrm{Fe}_{3} \mathrm{O}_{4}\right)_{1}(\mathrm{MgO})_{9}$ and $\left(\mathrm{Fe}_{3} \mathrm{O}_{4}\right)_{1.75}(\mathrm{MgO})_{8.25}$ catalyst, respectively. Figure 8 clearly shows SWNTs in a bundle form produced by the $\left(\mathrm{Fe}_{3} \mathrm{O}_{4}\right)_{1}(\mathrm{MgO})_{9}$ and $\left(\mathrm{Fe}_{3} \mathrm{O}_{4}\right)_{1.75}(\mathrm{MgO})_{8.25}$ catalysts. Under TEM observation, the diameter of these SWNTs was almost uniform and in agreement with the SEM observations (Figures 7(a) and 7(b)). Moreover, the SWNTs bundles possessed a high degree of graphitization, which is consistent with the Raman results (Figure 6).

From these results, it is clear that there is an optimum $\mathrm{Fe}_{3} \mathrm{O}_{4}$ loading that leads to the formation of SWNTs of the desired quality. When increasing the $\mathrm{Fe}_{3} \mathrm{O}_{4}$ loading by more than 1.75 , the $I_{\mathrm{D}} / I_{\mathrm{G}}$ ratio also increased significantly, and large CNTs were clearly observed in the samples (Figures 7(c) and 7(d)). Increasing the $\mathrm{Fe}_{3} \mathrm{O}_{4}$ content is beneficial 


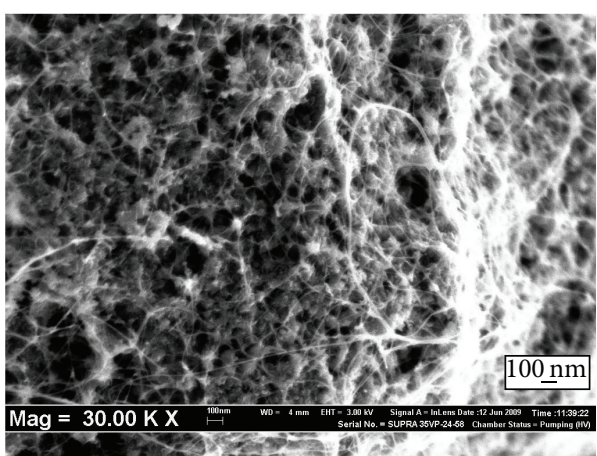

(a)

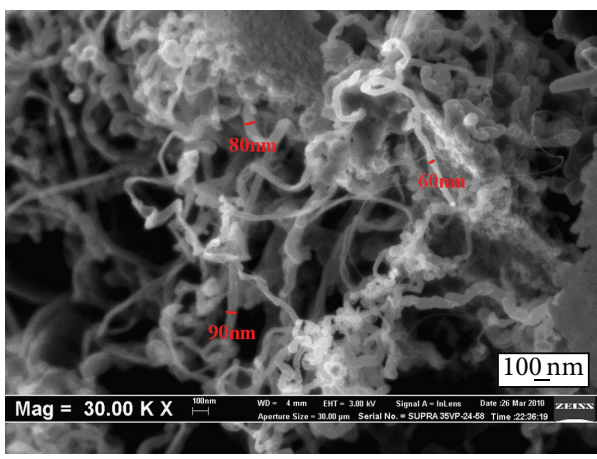

(c)

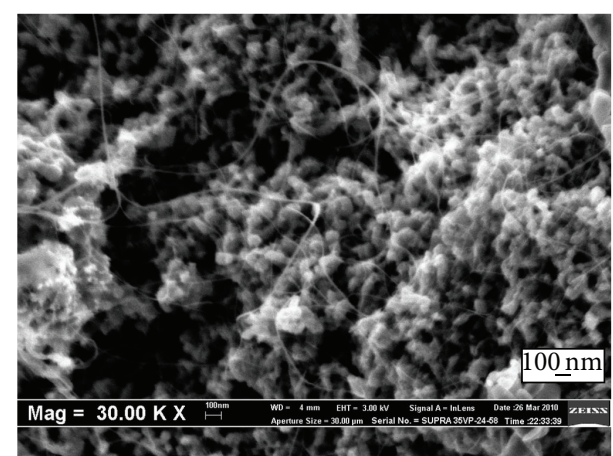

(b)

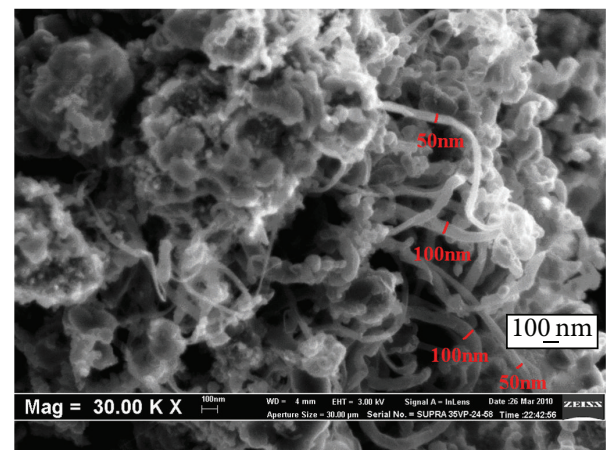

(d)

FIGURE 7: SEM images showing the CVD products synthesised using the (a) $\left(\mathrm{Fe}_{3} \mathrm{O}_{4}\right)_{1}(\mathrm{MgO})_{9},(\mathrm{~b})\left(\mathrm{Fe}_{3} \mathrm{O}_{4}\right)_{1.75}(\mathrm{MgO})_{8.25}, \quad(\mathrm{c})$ $\left(\mathrm{Fe}_{3} \mathrm{O}_{4}\right)_{2.5}(\mathrm{MgO})_{7.5}$, and $(\mathrm{d})\left(\mathrm{Fe}_{3} \mathrm{O}_{4}\right)_{3.25}(\mathrm{MgO})_{6.75}$ catalysts.

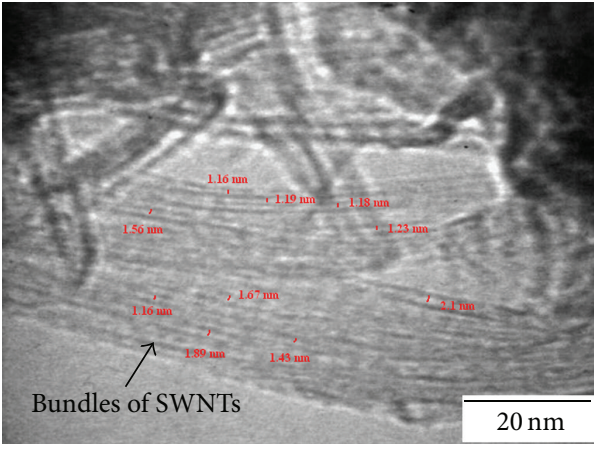

(a)

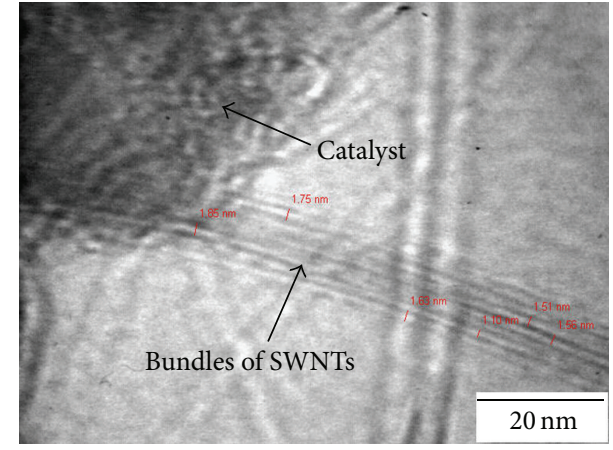

(b)

FIGURE 8: TEM images showing SWNT bundles synthesised using the (a) $\left(\mathrm{Fe}_{3} \mathrm{O}_{4}\right)_{1}(\mathrm{MgO})_{9}$ and (b) $\left(\mathrm{Fe}_{3} \mathrm{O}_{4}\right)_{1.75}(\mathrm{MgO})_{8.25}$ catalysts.

only if it enhances the available active sites for CNT growth, rather than increasing the nanoparticle sizes [43-47]. It is well known that the diameters of CNTs are correlated with active metal nanoparticles sizes [32, 40, 48-50]. Therefore, the narrow CNTs in this work were likely produced by small $\mathrm{Fe}_{3} \mathrm{O}_{4}$ nanoparticles, and the large CNTs by large $\mathrm{Fe}_{3} \mathrm{O}_{4}$ nanoparticles. Therefore, the quality of CNTs decreased with an increase in $\mathrm{Fe}_{3} \mathrm{O}_{4}$ loading.

The average size of $\mathrm{Fe}_{3} \mathrm{O}_{4}$ nanoparticles for $\left(\mathrm{Fe}_{3} \mathrm{O}_{4}\right)_{1}(\mathrm{MgO})_{9}$ catalyst was $10.33 \mathrm{~nm}$ as reported in our previous work [42]. In this work, the size of catalyst nanoparticles for the $\left(\mathrm{Fe}_{3} \mathrm{O}_{4}\right)_{1}(\mathrm{MgO})_{9}$ catalyst was much smaller than the size of catalyst nanoparticles for $\quad\left(\mathrm{Fe}_{3} \mathrm{O}_{4}\right)_{1.75}(\mathrm{MgO})_{8.25}, \quad\left(\mathrm{Fe}_{3} \mathrm{O}_{4}\right)_{2.5}(\mathrm{MgO})_{7.5}, \quad$ and $\left(\mathrm{Fe}_{3} \mathrm{O}_{4}\right)_{3.25}(\mathrm{MgO})_{6.75}$, as observed in Figure 7. The large nanoparticle catalysts were formed for the high $\mathrm{Fe}_{3} \mathrm{O}_{4}$ loaded: $\quad\left(\mathrm{Fe}_{3} \mathrm{O}_{4}\right)_{1.75}(\mathrm{MgO})_{8.25}, \quad\left(\mathrm{Fe}_{3} \mathrm{O}_{4}\right)_{2.5}(\mathrm{MgO})_{7.5}, \quad$ and $\left(\mathrm{Fe}_{3} \mathrm{O}_{4}\right)_{3.25}(\mathrm{MgO})_{6.75}$ catalysts due to the sintering of the $\mathrm{Fe}_{3} \mathrm{O}_{4}$ nanoparticles during reaction at high temperatures (i.e., $900^{\circ} \mathrm{C}$ ) [33]. Sintering is a thermally activated process that involves the diffusion of atoms [51]. Together with the higher concentration of iron, there would be a significantly higher degree of sintering of iron nanoparticles, causing large nanoparticles to form. However, it is believed that the degree of sintering of iron nanoparticles for $\left(\mathrm{Fe}_{3} \mathrm{O}_{4}\right)_{1}(\mathrm{MgO})_{9}$ was low compared with those of the $\left(\mathrm{Fe}_{3} \mathrm{O}_{4}\right)_{1.75}(\mathrm{MgO})_{8.25}$, 
$\left(\mathrm{Fe}_{3} \mathrm{O}_{4}\right)_{2.5}(\mathrm{MgO})_{7.5}$, and $\left(\mathrm{Fe}_{3} \mathrm{O}_{4}\right)_{3.25}(\mathrm{MgO})_{6.75}$ catalysts. As a result, the sizes of iron nanoparticles are small for a molar ratio of $1: 9$.

\section{Conclusion}

Our experimental findings show that among the types of active metals and supports investigated, $\mathrm{Fe}_{3} \mathrm{O}_{4}$ supported on $\mathrm{MgO}$ is the most suitable catalyst. High-quality SWNTs were synthesised using an $\mathrm{Fe}_{3} \mathrm{O}_{4} / \mathrm{MgO}$ catalyst with a molar ratio of $1: 9$. It is believed that iron has a higher carbon solubility than either cobalt or nickel, which helps to promote the formation of SWNTs. In addition, the interaction between $\mathrm{Fe}_{3} \mathrm{O}_{4}$ and $\mathrm{MgO}$ is strong, which prevents agglomeration of $\mathrm{Fe}_{3} \mathrm{O}_{4}$ and produces $\mathrm{CNTs}$ with a high degree of graphitisation. Using a low molar ratio of $\mathrm{Fe}_{3} \mathrm{O}_{4}$ to $\mathrm{MgO}$ could reduce the agglomeration of $\mathrm{Fe}_{3} \mathrm{O}_{4}$ nanoparticles. Therefore, the most suitable $\mathrm{Fe}_{3} \mathrm{O}_{4}$ loading found was at an $\mathrm{Fe}_{3} \mathrm{O}_{4}$ to $\mathrm{MgO}$ molar ratio of $1: 9$.

\section{Acknowledgments}

The authors gratefully acknowledge the financial support provided by the Universiti Sains Malaysia under Fundamental Research Grant Scheme (FRGS) (Project A/C no. 6071002), the Research University Grant (RU) (Project A/C no. 814004), Skim Penyelidikan Siswazah Universiti Penyelidikan (USMRU-PRGS) (Project A/C no. 8042015), and Universiti Sains Malaysia Fellowship.

\section{References}

[1] R. Andrews, D. Jacques, D. Qian, and T. Rantell, "Multiwall carbon nanotubes: synthesis and application," Accounts of Chemical Research, vol. 35, no. 12, pp. 1008-1017, 2002.

[2] F. Danafar, A. Fakhru'l-Razi, M. A. M. Salleh, and D. R. A. Biak, "Fluidized bed catalytic chemical vapor deposition synthesis of carbon nanotubes-A review," Chemical Engineering Journal, vol. 155, no. 1-2, pp. 37-48, 2009.

[3] P. Zarabadi-Poor, A. Badiei, A. A. Yousefi, B. D. Fahlman, and A. Abbasi, "Catalytic chemical vapour deposition of carbon nanotubes using Fe-doped alumina catalysts," Catalysis Today, vol. 150, no. 1-2, pp. 100-106, 2010.

[4] W. Zhou, Z. Han, J. Wang et al., "Copper catalyzing growth of single-walled carbon nanotubes on substrates," Nano Letters, vol. 6, no. 12, pp. 2987-2990, 2006.

[5] S. Bhaviripudi, E. Mile, S. A. Steiner III et al., "CVD synthesis of single-walled carbon nanotubes from gold nanoparticle catalysts," Journal of the American Chemical Society, vol. 129, no. 6, pp. 1516-1517, 2007.

[6] D. Takagi, Y. Homma, H. Hibino, S. Suzuki, and Y. Kobayashi, "Single-walled carbon nanotube growth from highly activated metal nanoparticles," Nano Letters, vol. 6, no. 12, pp. 2642-2645, 2006.

[7] D. Yuan, L. Ding, H. Chu, Y. Feng, T. P. McNicholas, and J. Liu, "Horizontally aligned single-walled carbon nanotube on quartz from a large variety of metal catalysts," Nano Letters, vol. 8, no. 8, pp. 2576-2579, 2008.

[8] L. Bilu, R. Wencai, G. Libo et al., "Manganese-catalyzed surface growth of single-walled carbon nanotubes with high efficiency,"
Journal of Physical Chemistry C, vol. 112, no. 49, pp. 19231-19235, 2008.

[9] S.-Y. Lee, M. Yamada, and M. Miyake, "Synthesis of carbon nanotubes over gold nanoparticle supported catalysts," Carbon, vol. 43, no. 13, pp. 2654-2663, 2005.

[10] T. Tsoufis, L. Jankovic, D. Gournis, P. N. Trikalitis, and T. Bakas, "Evaluation of first-row transition metal oxides supported on clay minerals for catalytic growth of carbon nanostructures," Materials Science and Engineering B, vol. 152, no. 1-3, pp. 4449, 2008.

[11] Y. Qian, C. Wang, G. Ren, and B. Huang, "Surface growth of single-walled carbon nanotubes from ruthenium nanoparticles," Applied Surface Science, vol. 256, no. 12, pp. 4038-4041, 2010.

[12] M. Kumar and Y. Ando, "Chemical vapor deposition of carbon nanotubes: a review on growth mechanism and mass production," Journal of Nanoscience and Nanotechnology, vol. 10, no. 6, pp. 3739-3758, 2010.

[13] S. Hofmann, R. Blume, C. T. Wirth et al., "State of transition metal catalysts during carbon nanotube growth," Journal of Physical Chemistry C, vol. 113, no. 5, pp. 1648-1656, 2009.

[14] J. D. Núñez, W. K. Maser, M. Carmen Mayoral, J. M. Andrés, and A. M. Benito, "Platelet-like catalyst design for high yield production of multi-walled carbon nanotubes by catalytic chemical vapor deposition," Carbon, vol. 49, no. 7, pp. 24832491, 2011.

[15] H. Igarashi, H. Murakami, Y. Murakami, S. Maruyama, and N. Nakashima, "Purification and characterization of zeolitesupported single-walled carbon nanotubes catalytically synthesized from ethanol," Chemical Physics Letters, vol. 392, no. 4-6, pp. 529-532, 2004.

[16] I. Schmidt, A. Boisen, E. Gustavsson et al., "Carbon nanotube templated growth of mesoporous zeolite single crystals," Chemistry of Materials, vol. 13, no. 12, pp. 4416-4418, 2001.

[17] J. M. Cao, "Selective growth of carbon nantoubes on $\mathrm{SiO}_{2} / \mathrm{Si}$ substrate," Applied Surface Science, vol. 253, no. 5, pp. 24602464, 2006.

[18] H. Ohno, D. Takagi, K. Yamada, S. Chiashi, A. Tokura, and Y. Homma, "Growth of vertically aligned single-walled carbon nanotubes on alumina and sapphire substrates," Japanese Journal of Applied Physics, vol. 47, no. 4, pp. 1956-1960, 2008.

[19] C.-T. Hsieh, Y.-T. Lin, J.-Y. Lin, and J.-L. Wei, "Synthesis of carbon nanotubes over Ni- and Co-supported $\mathrm{CaCO}_{3}$ catalysts using catalytic chemical vapor deposition," Materials Chemistry and Physics, vol. 114, no. 2-3, pp. 702-708, 2009.

[20] G.-Y. Xiong, D. Z. Wang, and Z. F. Ren, "Aligned millimeterlong carbon nanotube arrays grown on single crystal magnesia," Carbon, vol. 44, no. 5, pp. 969-973, 2006.

[21] M. Picher, E. Anglaret, R. Arenal, and V. Jourdain, "Processes controlling the diameter distribution of single-walled carbon nanotubes during catalytic chemical vapor deposition," ACS Nano, vol. 5, no. 3, pp. 2118-2125, 2011.

[22] Y. Tian, M. Y. Timmermans, M. Partanen et al., "Growth of single-walled carbon nanotubes with controlled diameters and lengths by an aerosol method," Carbon, vol. 49, no. 14, pp. 46364643, 2011

[23] L. Vanyorek, D. Loche, H. Katona et al., "Optimization of the catalytic chemical vapor deposition synthesis of multiwall carbon nanotubes on $\mathrm{FeCo}(\mathrm{Ni}) / \mathrm{SiO}_{2}$ aerogel catalysts by statistical design of experiments," Journal of Physical Chemistry C, vol. 115, no. 13, pp. 5894-5902, 2011. 
[24] H. S. Yang, L. Zhang, X. H. Dong et al., "Precise control of the number of walls formed during carbon nanotube growth using chemical vapor deposition," Nanotechnology, vol. 23, no. 6, Article ID 065604, 2012.

[25] O. C. Carneiro, P. E. Anderson, N. M. Rodriguez, and R. T. K. Baker, "Synthesis of high purity narrow-width carbon nanotubes," Carbon, vol. 50, no. 9, pp. 3200-3209, 2012.

[26] W.-W. Liu, A. Aziz, S.-P. Chai, C.-T. Tye, and A. R. Mohamed, "Broad bundles of single-walled carbon nanotube synthesized over $\mathrm{Fe}_{2} \mathrm{O}_{3} / \mathrm{MgO}$ via chemical vapor deposition of methane," Nano, vol. 4, no. 2, pp. 77-81, 2009.

[27] W.-W. Liu, A. Aziz, S.-P. Chai, A. R. Mohamed, and C.-T. Tye, "Optimisation of reaction conditions for the synthesis of singlewalled carbon nanotubes using response surface methodology," Canadian Journal of Chemical Engineering, vol. 90, no. 2, pp. 489-505, 2012.

[28] W.-W. Liu, A. Azizan, S.-P. Chai, R. M. Abdul, and C.-T. Tye, "Preparation of iron oxide nanoparticles supported on magnesium oxide for producing high-quality single-walled carbon nanotubes," New Carbon Materials, vol. 26, no. 4, pp. 255-261, 2011.

[29] W.-W. Liu, A. Aziz, S.-P. Chai, A. R. Mohamed, and C.-T. Tye, "The effect of carbon precursors (methane, benzene and camphor) on the quality of carbon nanotubes synthesised by the chemical vapour decomposition," Physica E, vol. 43, no. 8, pp. 1535-1542, 2011.

[30] M. S. Dresselhaus, G. Dresselhaus, R. Saito, and A. Jorio, "Raman spectroscopy of carbon nanotubes," Physics Reports, vol. 409, no. 2, pp. 47-99, 2005.

[31] A. Moisala, A. G. Nasibulin, and E. I. Kauppinen, "The role of metal nanoparticles in the catalytic production of single-walled carbon nanotubes: a review," Journal of Physics Condensed Matter, vol. 15, no. 42, pp. S3011-S3035, 2003.

[32] K. J. MacKenzie, O. M. Dunens, and A. T. Harris, "An updated review of synthesis parameters and growth mechanisms for carbon nanotubes in fluidized beds," Industrial and Engineering Chemistry Research, vol. 49, no. 11, pp. 5323-5338, 2010.

[33] V. L. Kuznetsov, A. N. Usol'tseva, and Y. V. Butenko, "Mechanism of coking on metal catalyst surfaces: I. Thermodynamic analysis of nucleation," Kinetics and Catalysis, vol. 44, no. 5, pp. 726-734, 2003.

[34] M. S. Dresselhaus, G. Dresselhaus, A. Jorio, A. G. Souza Filho, M. A. Pimenta, and R. Saito, "Single nanotube Raman spectroscopy," Accounts of Chemical Research, vol. 35, no. 12, pp. 1070-1078, 2002.

[35] H. Ago, K. Nakamura, S. Imamura, and M. Tsuji, "Growth of double-wall carbon nanotubes with diameter-controlled iron oxide nanoparticles supported on MgO," Chemical Physics Letters, vol. 391, no. 4-6, pp. 308-313, 2004.

[36] Y. Jin, G. W. Wang, and Y. D. Li, "Catalytic growth of high quality single-walled carbon nanotubes over a Fe/MgO catalyst derived from a precursor containing Feitknecht compound," Applied Catalysis A, vol. 445-446, pp. 121-127, 2012.

[37] H. Ago, K. Nakamura, N. Uehara, and M. Tsuji, "Roles of metal-support interaction in growth of single- and doublewalled carbon nanotubes studied with diameter-controlled iron particles supported on MgO," Journal of Physical Chemistry B, vol. 108, no. 49, pp. 18908-18915, 2004.

[38] H. Ago, S. Imamura, T. Okazaki, T. Saito, M. Yumura, and M. Tsuji, "CVD growth of single-walled carbon nanotubes with narrow diameter distribution over $\mathrm{Fe} / \mathrm{MgO}$ catalyst and their fluorescence spectroscopy," Journal of Physical Chemistry B, vol. 109, no. 20, pp. 10035-10041, 2005.

[39] A.-C. Dupuis, "The catalyst in the CCVD of carbon nanotubes-a review," Progress in Materials Science, vol. 50, no. 8, pp. 929-961, 2005.

[40] C. Sun and J. C. Berg, "A review of the different techniques for solid surface acid-base characterization," Advances in Colloid and Interface Science, vol. 105, no. 1-3, pp. 151-175, 2003.

[41] J. Kong, A. M. Cassell, and H. Dai, "Chemical vapor deposition of methane for single-walled carbon nanotubes," Chemical Physics Letters, vol. 292, no. 4-6, pp. 567-574, 1998.

[42] A. M. Cassell, J. A. Raymakers, J. Kong, and H. Dai, "Large scale CVD synthesis of single-walled carbon nanotubes," Journal of Physical Chemistry B, vol. 103, no. 31, pp. 6484-6492, 1999.

[43] J. E. Herrera, L. Balzano, A. Borgna, W. E. Alvarez, and D. E. Resasco, "Relationship between the structure/composition of Co-Mo catalysts and their ability to produce single-walled carbon nanotubes by CO disproportionation," Journal of Catalysis, vol. 204, no. 1, pp. 129-145, 2001.

[44] X. Z. Liao, A. Serquis, Q. X. Jia, D. E. Peterson, Y. T. Zhu, and H. F. Xu, "Effect of catalyst composition on carbon nanotube growth," Applied Physics Letters, vol. 82, no. 16, pp. 2694-2696, 2003.

[45] Y. Yao, L. K. L. Falk, R. E. Morjan, O. A. Nerushev, and E. E. B. Campbell, "Synthesis of carbon nanotube films by thermal CVD in the presence of supported catalyst particles. Part II: the nanotube film," Journal of Materials Science, vol. 15, no. 9, pp. 583-594, 2004.

[46] K. B. Kouravelou and S. V. Sotirchos, "Dynamic study of carbon nanotubes production by chemical vapor deposition of alcohols," Reviews on Advanced Materials Science, vol. 10, no. 3, pp. 243-248, 2005.

[47] L. Zheng, X. Liao, and Y. T. Zhu, "Parametric study of carbon nanotube growth via cobalt-catalyzed ethanol decomposition," Materials Letters, vol. 60, no. 16, pp. 1968-1972, 2006.

[48] M. Su, Y. Li, B. Maynor, A. Buldum, J. P. Lu, and J. Liu, "Latticeoriented growth of single-walled carbon nanotubes," Journal of Physical Chemistry B, vol. 104, no. 28, pp. 6507-6508, 2000.

[49] Y. Li, J. Liu, Y. Wang, and Z. L. Wang, "Preparation of monodispersed Fe-Mo nanoparticles as the catalyst for CVD synthesis of carbon nanotubes," Chemistry of Materials, vol. 13, no. 3, pp. 1008-1014, 2001.

[50] Y. Zhang, Y. Li, W. Kim, D. Wang, and H. Dai, "Imaging asgrown single-walled carbon nanotubes originated from isolated catalytic nanoparticles," Applied Physics A, vol. 74, no. 3, pp. 325-328, 2002.

[51] R. M. German, Powder Metallurgy Science, vol. 24, Princeton, New Jersey, NJ, USA, 1984. 

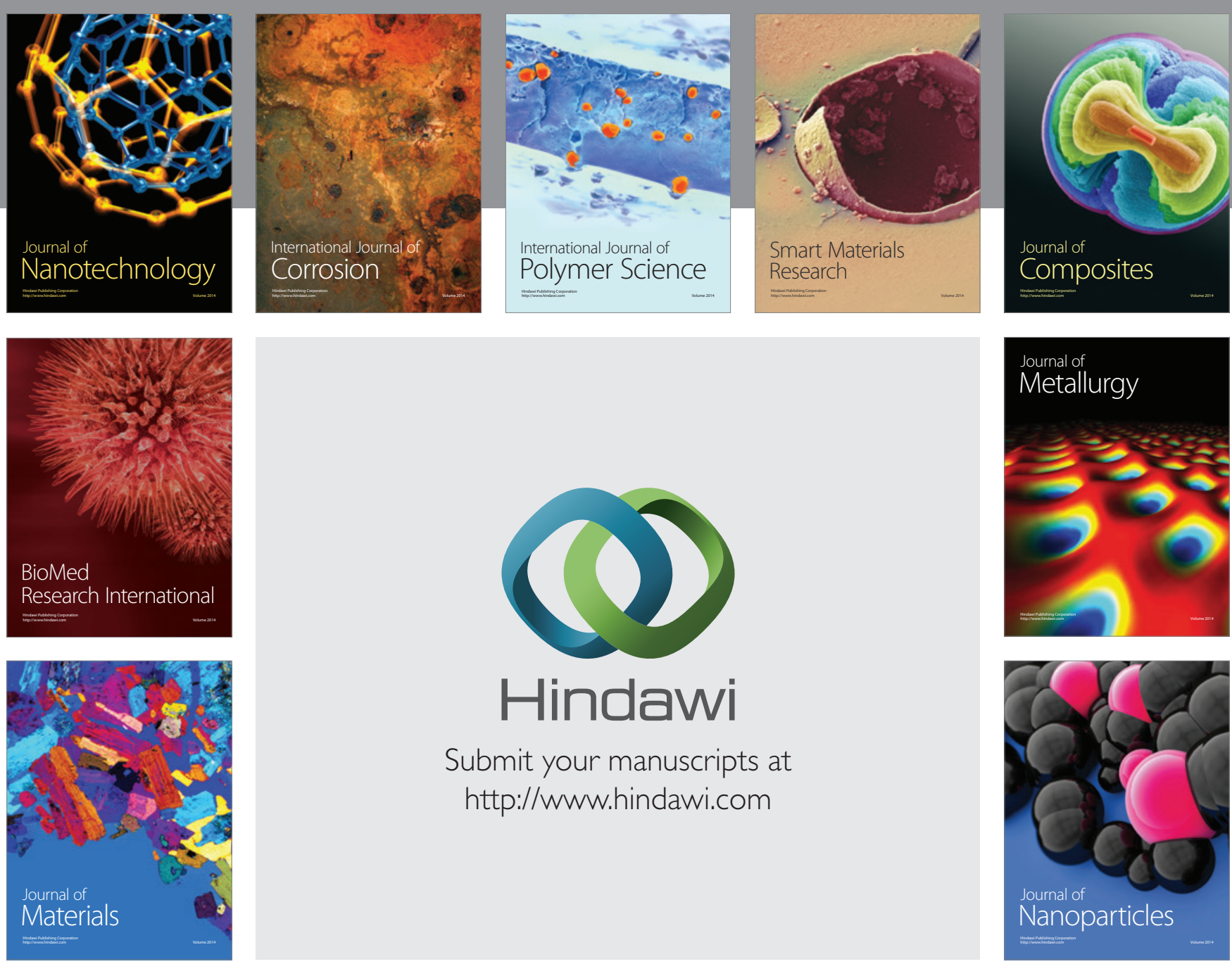

Submit your manuscripts at http://www.hindawi.com
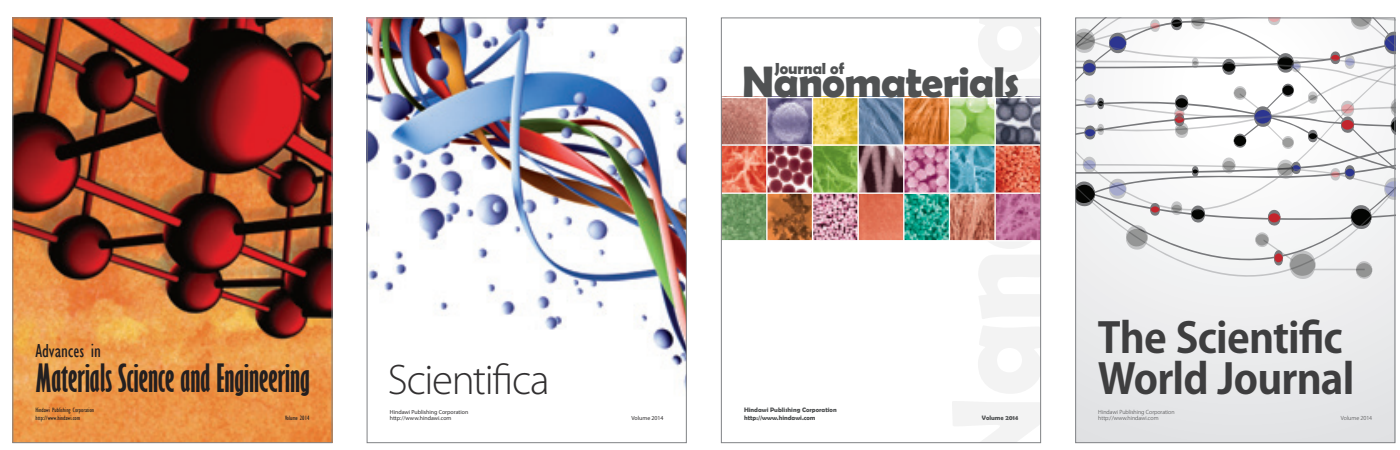

\section{The Scientific World Journal}
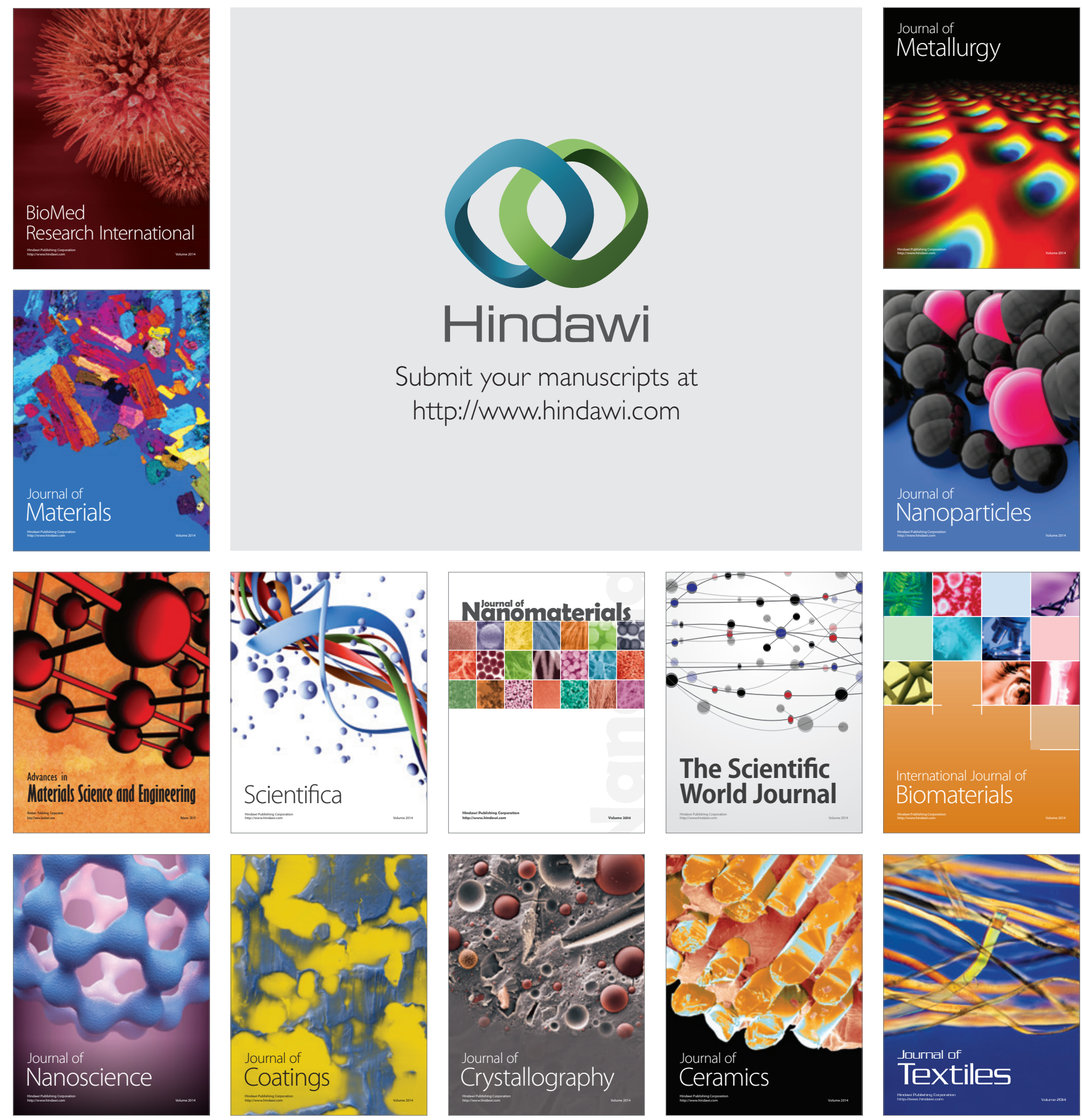